\title{
APPLICATION OF PATIENT FUNCTION RECOVERY AFTER RECONSTRUCTION OF THE ANTERIOR CRUCIATE LIGAMENT
}

\author{
APLICAÇÃO DA RECUPERAÇÃO DA FUNÇÃO DO PACIENTE DEPOIS DE RECONSTRUÇÃO DO LIGAMENTO \\ CRUZADO ANTERIOR
}

Original Article ARTIGO ORIGINAL Artículo Original

\author{
APLICACIÓN DE LA RECUPERACIÓN DE LA FUNCIÓN DEL PACIENTE TRAS LA RECONSTRUCCIÓNDEL \\ LIGAMENTO CRUZADO ANTERIOR
}

\section{Xun Su' (iD) \\ (Physician)}

1. Hospital NO.363, Orthopaedics Department, Chengdu, China.

\section{Correspondence:}

Xun Su

Chengdu, China. 610000

Sue0550@163.com

\begin{abstract}
Introduction: The anterior cruciate ligament $(A C L)$ is one of the important structures of knee joint stability. Objective: To investigate the application of medical training therapy (MTT) in the functional recovery of patients after anterior cruciate ligament reconstruction. Methods: Eighty patients who were treated in a secondary hospital were selected as the study subjects and were divided into a control group and an observation group according to a random number meter, with 40 cases per group. We compared Lysholm knee function scores, the range of motion (ROM), daily life capability (ADL scale), pain degree (VAS rating), knee stretch muscle score, and standing balance ability score of the two groups 3 months after intervention. Results: After intervention, the first time getting out of bed, the doctor-patient satisfaction score, and the average length of stay were better in the observation group than in the control group $(P<0.05)$. The excellent rate of knee function in the observation group was $92.50 \%$, which was significantly higher than $70.00 \%$ in the control group $(P<0.05)$. Conclusions: MTT therapy can significantly improve knee the function and pain level of patients after anterior cruciate ligament reconstruction, shorten the length of hospital stay, promote rehabilitation, improve the therapeutic effect, and improve the quality of life of patients. Level of evidence Il; Therapeutic studies - investigation of treatment results.
\end{abstract}

Keywords: Academic medical centers; Knee joint; Functional.

\section{RESUMO}

Introdução: O ligamento cruzado anterior (LCA) é uma das estruturas importantes para a estabilidade da articulação do joelho. Objetivo: Investigar a aplicação da terapia de treinamento médico (MTT) na recuperação funcional de pacientes depois de reconstrução do ligamento cruzado anterior. Métodos: Oitenta pacientes tratados em um hospital secundário foram selecionados como participantes do estudo e foram divididos em grupo controle e grupo observação com um gerador de números aleatórios, com 40 casos por grupo. Comparamos os escores de função do joelho de Lysholm, a amplitude de movimento (ROM), capacidade de vida diária (escala ADL), grau de dor (classificação EVA), escore do músculo de alongamento do joelho e escore da capacidade de equilibrio em pé dos dois grupos, três meses depois da intervenção. Resultados: Depois da intervenção, na primeira vez em que os pacientes levantaram da cama, o índice de satisfação médico-paciente e o tempo médio de permanência foram melhores no grupo observação do que no grupo controle $(P<0,05)$. A excelente taxa de função do joelho no grupo observação foi de $92,50 \%$, que foi significativamente maior do que 70,00\% no grupo controle $(P<0,05)$. Conclusões: A terapia de MTT pode melhorar significativamente a função e o nivel de dor do joelho em pacientes depois da reconstrução do ligamento cruzado anterior, reduzir o tempo de internação, promover a reabilitação, melhorar o efeito terapêutico e melhorar a qualidade de vida dos pacientes. Nível de Evidência Il; Estudos terapêuticos - Investigação dos resultados do tratamento.

Descritores: Centros médicos acadêmicos; Articulação do joelho; Funcional.

\section{RESUMEN}

Introducción: El ligamento cruzado anterior (LCA) es una de las estructuras importantes para la estabilidad de la articulación de la rodilla. Objetivo: Investigar la aplicación de la terapia de entrenamiento médico (MTT) en la recuperación funcional de pacientes tras la reconstrucción del ligamento cruzado anterior. Métodos: Se seleccionaron como participantes en el estudio 80 pacientes tratados en un hospital secundario y se dividieron en un grupo de control y otro de observación con un generador de números aleatorios, con 40 casos por grupo. Se compararon las puntuaciones de la función de la rodilla de Lysholm, la amplitud de movimiento (ROM), la capacidad de la vida diaria (escala ADL), el grado de dolor (clasificación EVA), la puntuación del músculo extensor de la rodilla y la puntuación de la capacidad de equilibrio de pie de los dos grupos tres meses después de la intervención. Resultados: Tras la intervención, la primera vez que los pacientes se levantaron de la cama, el índice de satisfacción médico-paciente y el tiempo medio de internación fueron mejores en el grupo de observación que en el grupo de control $(p<0,05)$. La excelente tasa de función de la rodilla en el grupo de observación fue del 92,50\%, significativamente superior al 70,00\% del grupo de control $(P<0,05)$. Conclusiones: La terapia de MTT 
puede mejorar significativamente la función y el nivel de dolor de la rodilla en pacientes tras la reconstrucción del ligamento cruzado anterior, reducir el tiempo de internación hospitalaria, promover la rehabilitación, mejorar el efecto terapéutico y mejorar la calidad de vida de los pacientes. Nivel de Evidencia II; Estudios terapéuticos Investigación de los resultados del tratamiento.

Descriptores: Centros médicos académicos; Articulación de la rodilla; Funcional.

\section{INTRODUCTION}

Anterior cruciate ligament (ACL) is one of the important structure of knee joint stability and after its damage can lead to knee before - and rotational instability, which in turn can cause the meniscus and articular cartilage injury, accelerate the degeneration of the knee joint, the forward will induce a variety of secondary diseases such as osteoarthritis, seriously affect the patient's daily life and movement. Factors causing ACL injury include active sports and traffic injuries, etc., and age, gender, side and knee position during injury have important influence on $\mathrm{ACL}$ injury. ${ }^{1}$ Anterior cruciate ligament reconstruction is the main method for the treatment of $A C L$ injury, but postoperative rehabilitation can benefit the recovery of knee function and shorten the recovery time. To understand the application of professional rehabilitation methods in postoperative rehabilitation of anterior cruciate ligament reconstruction of knee joint, and to establish postoperative rehabilitation training standards and norms for anterior cruciate ligament reconstruction of knee joint, to maximize the recovery of patients' motor function, so as to solve the prominent and urgent problems in the rehabilitation of acl injury. ${ }^{2}$

\section{METHOD}

\section{The general information}

A total of 80 patients treated in a hospital from January 2015 to June 2017 after anterior cruciate ligament reconstruction were selected as the research object. Inclusion criteria: confirmed by joint MRI, front drawer test and axial shift test. Exclusion criteria: Serious diseases of heart, liver, lung, kidney and other important organs were excluded. Patients with intra-knee fracture and serious articular cartilage injury were excluded. According to the random number table method, patients were divided into control group and observation group, 40 cases in each group. In the control group, there were 23 males and 17 females. Age range: 22-55; There were 18 cases of left knee joint injury and 22 cases of right knee joint injury. The causes of injury were sports injury 18 cases, traffic accident injury 10 cases, daily life injury 12 cases. In observation group, there were 24 males and 16 females. Age range: 23 to 56; There were 16 cases of left knee joint injury and 24 cases of right knee joint injury. The causes of injury were sports injury in 15 cases, traffic accident injury in 12 cases and daily life injury in 13 cases. There was no significant difference in general data between the two groups ( $P>0.05$ ), indicating comparability.

\section{METHODS}

\section{The control group}

Routine rehabilitation treatment is given, patients are encouraged to carry out independent rehabilitation training under the guidance of doctors, and patients are encouraged to move to the ground at an early stage, advantages and methods of moving to the ground are explained in detail to patients, and patients can be assisted to move out of bed when necessary. ${ }^{3}$

\section{Observation group}

Routine rehabilitation and MTT therapy were given for rehabilitation. (1) Balance test and training system: proprioception assessment was conducted to find out the cause of postoperative balance loss, and the same tester was used to test the patient. (2) Targeted balance and motion control training, including sitting balance, static balance and dynamic balance training. ${ }^{4}$

\section{Observation indicators and criteria}

(1) The time to get out of bed for the first time, doctor-patient satisfaction and average length of hospital stay were compared between the two groups, a self-made questionnaire was used to evaluate doctor-patient satisfaction, with a total of 21 questions and a total score of 0 21 points. The higher the score, the higher the satisfaction. (2) Lysholm knee function score was used to compare the knee function of the two groups before and 3 months after intervention, the total score ranges from 0 to 100, with above 95 being excellent, 94 to 85 good, 84 to 65 fair, and below 65 poor, excellent and good rate $=$ (number of excellent cases + number of good cases)/total cases $\times 100 \%$; (3) Range of motion (ROM) before and 3 months after intervention was observed in both groups. ${ }^{5-6}$ There was no significant correlation in the observation group, the correlation coefficients were 0.485 and 0.388 , and the significance levels were 0.270 and 0.420 , respectively. (Figure 1)

\section{Statistical Treatment}

SPSS 19.0 software was used for statistical analysis of the obtained data, and the measurement data was represented by $(x \pm s)$. T-test was used for comparison between groups. The count data were expressed in percentage (\%) and compared with $x^{2}$ test. $P<0.05$ was considered as statistically significant difference.

\section{RESULTS}

Comparison of general conditions after rehabilitation intervention between the two groups The first time to get out of bed, doctor-patient satisfaction and average length of stay in the observation group were better than those in the control group, with statistical significance $(P<0.05)$. (Table 1)

Comparison of the recovery of knee function between the two groups before intervention, there was no statistical significance in Lysholm score and ROM between the two groups ( $P>0.05)$. After intervention, Lysholm

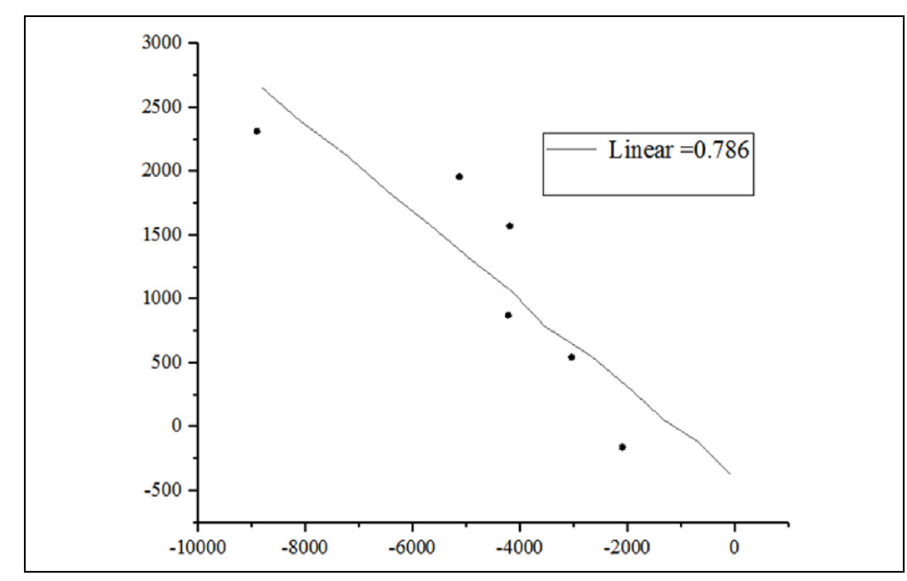

Figure 1. High negative variation of the two groups. 
score and ROM of the observation group were significantly better than those of the control group $(P<0.05)$. The excellent rate of knee function in the observation group was $92.50 \%$ (37/40), which was significantly higher than that in the control group (70.00\% (28/40), and the difference was statistically significant $(P<0.05)$. (Table 2$)$

Comparison of ADL, VAS, knee extensor muscle strength and standing balance scores between the two groups before intervention, there were no significant differences in ADL, VAS, knee extensor muscle strength and standing balance scores between the two groups ( $P>0.05)$. After intervention, $A D L$, VAS, knee extensor muscle strength and standing balance score of observation group were improved compared with control group ( $P<0.05)$. (Table 3)

\section{DISCUSSION}

MTT therapy includes training of balance and coordination ability, proprioceptive function, walking gait, muscle strength, endurance, range of motion and other aspects, with obvious characteristics of systematicness, initiative and planning. ${ }^{7}$ Targeted MTT therapy can effectively improve physical function and maintain maximum bone mass in young people, muscle strength and mass can also be improved in older adults with common MTT therapy. The training device of MTT therapy makes the training mode suitable for patients with different injuries and training needs, according to the patient's routine physiological situation and state, individual medical diagnosis results,pain and individual joint range of motion allowed by individual muscle function, so that training can be carried out in an effective, individual and targeted way ${ }^{[8]}$. Inducing neuromuscular adaptive changes is an important mechanism of MTT therapy, which can induce and adapt the

Table 1. Comparison of general situation between the two groups after rehabilitation intervention $(\bar{x} \pm s)$.

\begin{tabular}{c|c|c|c}
\hline Group & $\begin{array}{c}\text { First time out } \\
\text { of bed (d) }\end{array}$ & $\begin{array}{c}\text { Doctor-patient } \\
\text { satisfaction (points) }\end{array}$ & $\begin{array}{c}\text { Average length } \\
\text { of stay (d) }\end{array}$ \\
\hline $\begin{array}{c}\text { The control } \\
\text { group }(n=40)\end{array}$ & $3.35 \pm 1.24$ & $14.52 \pm 2.14$ & $19.24 \pm 2.64$ \\
\hline $\begin{array}{c}\text { Observation } \\
\text { group }(n=40)\end{array}$ & $1.25 \pm 1.13$ & $18.54 \pm 2.36$ & $13.18 \pm 2.31$ \\
\hline T value & 7.917 & 7.981 & 10.926 \\
\hline P value & $<0.001$ & $<0.001$ & $<0.001$ \\
\hline
\end{tabular}

nervous system at different levels to set training prescriptions individually according to the assessment situation, this greatly enhances the systematicness and pertinency of treatment, thus ensuring the quality of treatment for each patient undergoing MTT therapy training. ${ }^{9-10}$

\section{CONCLUSION}

This study explored the application of MTT therapy in functional recovery of patients after anterior fork ligament reconstruction of the knee joint, the results showed that Lysholm score and ROM of the observation group were significantly better than those of the control group after rehabilitation intervention $(P<0.05)$, ADL, VAS, knee extensor muscle strength and standing balance score in observation group were improved compared with control group $(P<0.05)$. The time to get out of bed for the first time, the satisfaction degree of both doctors and patients and the average length of hospital stay in the observation group were better than those in the control group $(P<0.05)$, the excellent rate of knee function in the observation group was $92.50 \%$, which was significantly higher than that in the control group (70.00\%). In conclusion, MTT therapy training can significantly improve the knee function of patients after anterior cruciate ligament reconstruction, reduce the degree of pain, shorten the length of hospital stay, promote rehabilitation, improve the treatment effect, and improve the quality of life of patients, which is worthy of clinical application.

The author declare no potential conflict of interest related to this article

Table 2. Comparison of functional recovery of knee joint between the two groups.

\begin{tabular}{c|c|c|c|c|c}
\hline \multirow{2}{*}{ Group } & \multicolumn{2}{|c|}{ Lysholm score } & \multirow{2}{*}{$\begin{array}{c}\text { Excellent } \\
\text { and good }\end{array}$} & \multicolumn{2}{c}{ ROM } \\
\cline { 2 - 3 } & $\begin{array}{c}\text { Before the } \\
\text { intervention }\end{array}$ & $\begin{array}{c}\text { After the } \\
\text { intervention }\end{array}$ & $\begin{array}{c}\text { Before the } \\
\text { rate (\%) } \\
\text { intervention }\end{array}$ & $\begin{array}{c}\text { After the } \\
\text { intervention }\end{array}$ \\
\hline $\begin{array}{c}\text { The control } \\
\text { group (n=40) }\end{array}$ & $46.55 \pm 4.34$ & $83.32 \pm 3.24$ & 28 & $35.36 \pm 2.64$ & $84.24 \pm 4.62$ \\
\hline $\begin{array}{c}\text { Observation } \\
\text { group (n=40) }\end{array}$ & $46.58 \pm 4.41$ & $92.41 \pm 3.39$ & 37 & $35.41 \pm 2.51$ & $119.42 \pm 7.53$ \\
\hline T value & 0.031 & 12.260 & 6.646 & 0.087 & 25.186 \\
\hline P value & 0.975 & $<0.001$ & $<0.05$ & 0.931 & $<0.001$ \\
\hline
\end{tabular}

Table 3. Comparison of ADL, VAS, knee extensor muscle strength and standing balance between the two groups ( $\bar{x} \pm s$ ).

\begin{tabular}{|c|c|c|c|c|c|c|c|c|}
\hline \multirow[t]{2}{*}{ Group } & \multicolumn{2}{|c|}{ Lysholm score } & \multicolumn{2}{|c|}{ And strength. } & \multicolumn{2}{|c|}{ Standing balance } & \multicolumn{2}{|c|}{ VAS score } \\
\hline & $\begin{array}{c}\text { Before the } \\
\text { intervention }\end{array}$ & $\begin{array}{c}\text { After the } \\
\text { intervention }\end{array}$ & $\begin{array}{c}\text { Before the } \\
\text { intervention }\end{array}$ & $\begin{array}{c}\text { After the } \\
\text { intervention }\end{array}$ & $\begin{array}{c}\text { Before the } \\
\text { intervention }\end{array}$ & $\begin{array}{c}\text { After the } \\
\text { intervention }\end{array}$ & $\begin{array}{c}\text { Before the } \\
\text { intervention }\end{array}$ & $\begin{array}{c}\text { After the } \\
\text { intervention }\end{array}$ \\
\hline $\begin{array}{c}\text { The control } \\
\text { group }(n=40)\end{array}$ & $52.04 \pm 3.21$ & $72.34 \pm 4.18$ & $6.32 \pm 1.24$ & $7.21 \pm 1.34$ & $3.26 \pm 1.16$ & $4.34 \pm 1.16$ & $5.42 \pm 1.31$ & $3.31 \pm 1.15$ \\
\hline $\begin{array}{l}\text { Observation } \\
\text { group }(n=40)\end{array}$ & $53.01 \pm 3.18$ & $85.23 \pm 4.21$ & $6.35 \pm 1.13$ & $8.36 \pm 1.12$ & $3.28 \pm 1.14$ & $5.28 \pm 1.13$ & $5.45 \pm 1.36$ & $2.53 \pm 0.28$ \\
\hline T value & 1.358 & 13.741 & 0.113 & 4.165 & 0.078 & 3.671 & 0.100 & 4.168 \\
\hline$P$ value & 0.178 & $<0.001$ & 0.910 & $<0.001$ & 0.938 & $<0.001$ & 0.921 & $<0.001$ \\
\hline
\end{tabular}

AUTHORS' CONTRIBUTIONS: The author made significant contributions to this manuscript. Xun Su: writing and performing surgeries, data analysis and performing surgeries and article review and intellectual concept of the article.

\section{REFERENCES}

1. Akhtyamov IF, Aidarov VI, Khasanov ER. Current methods of rehabilitation after arthroscopic reconstruction of the anterior cruciate ligament of the knee joint (review of literature). Genij Ortop. 2021;27(1):121-7.

2. Huang A, Singh PA, Woon KL. Interspace between the popliteal artery and the capsule of the knee (ipack) block for anterior cruciate ligament reconstruction surgery: a two case series. Open J Anesthesiol. 2020;10(4):134-43.

3. Zayats VV, Dulaev AK, Zagorodnii NV, Dydykin AV, Ulianchenko IN. Functional results of surgical reconstruction of the anterior cruciate ligament of the knee joint in combination with lateral stabilization. Vestn Khirurgii Im I.I. Grek. 2019;178(1):39-44.

4. Sajjadi MM, Zandi R, Ebrahimpour A, Okhovatpour MA, Kafiabadi MJ. Clinical and functional outcomes of early collateral ligament and late cruciate ligament reconstructions in multi-ligament knee injuries; a prospective, cross-sectional study. Trauma Mon. 2020;25(1):14-9.

5. Ahmed MM, Amin W, Ayoub A, Zaino M, Hommadi RM, Haddadi ZH, et al. Influence of virtual reality games on knee proprioception after anterior cruciate ligament reconstruction (aclr). Jokull. 2020;69(11):15-35.
6. Zayats VV, Dulaev AK, Dydykin AV, Ulyanchenko IN. Clinical evaluation of anatomical reconstruction of the anterior cruciate ligament. Genij Ortop. 2021;27(1):48-54.

7. Alm L, Drenck TC, Frosch KH, Akoto R. Lateral extra-articular tenodesis in patients with revision anterior cruciate ligament $(\mathrm{acl})$ reconstruction and high-grade anterior knee instability. Knee. 2020;27(5):1451-7.

8. Yan W, Xu X, Qian X, Ziying S, Chen D, Xu Z, et al. In vivo gait kinematics of the knee after anatomical and non-anatomical single-bundle anterior cruciate ligament reconstruction-a prospective study. Ann Transl Med. 2019;7(24):799-799.

9. Yang XG, Wang F, He X, Feng JT, Hu YC, Zhang Het al. Network meta-analysis of knee outcomes following anterior cruciate ligament reconstruction with various types of tendon grafts. Int Orthop 2020;44(2):365-80

10. Thaunat $M$, Ingale PS, Guise JD, Dumas $R$, Blache $Y$. The effect of anterolateral ligament reconstruction on knee constraint: a computer model-based simulation study. Knee. 2020;27(4):1228-37. 